\title{
Local immune responses in certain extra-articular manifestations of rheumatoid arthritis
}

\author{
James T Halla, Ralph E Schrohenloher, William J Koopman
}

Significant progress has been made in the characterisation of immunological events occurring in the synovium of patients with rheumatoid arthritis (RA). Synthesis in the synovium of immunoreactants present in locally deposited immune complexes has been well documented. ${ }^{1-12}$ These local humoral immune responses almost certainly play a part in the perpetuation of tissue injury in the joint and perhaps in the initial development of the articular manifestations of RA. ${ }^{12}$

Extra-articular manifestations of RA are well recognised and include involvement of the pleura, pericardium, and muscle. Their occurrence increases with the duration and severity of the peripheral joint disease. ${ }^{1}$ The term 'rheumatoid disease' is preferred when considering extra-articular manifestations to indicate the systemic nature of the disease. Many extraarticular manifestations of RA are attributed to vasculitis, or remain undefined pathogenetically. ${ }^{1-13}$ Studies have provided insights about the possible part played by local humoral immune responses in the pathogenesis of at least some extra-articular manifestations of RA. ${ }^{14-18}$

This paper reviews the evidence suggesting that local humoral immune responses occur in some extra-articular manifestations of RA and considers the implications of these observations.

\section{Pleural disease}

Pleural disease in RA is well recognised and is often seen at necropsy. ${ }^{1314} 19$ Clinical manifestations, although less common, consist of an asymptomatic effusion or pleuritis with or without fever. The pleural fluid characteristically contains reduced complement activity, complement activation products, phagocytic cells containing immune reactants, and immune complexes which differ qualitatively from those found in serum samples, but similar to those found in synovial fluid. ${ }^{14} 1520$

These observations suggest the presence of local humoral immune responses in rheumatoid pleuritis as opposed to local deposition of circulating immune complexes. To investigate this possibility, three patients with rheumatoid pleuritis were studied. ${ }^{16}$ De novo synthesis of IgM and IgM rheumatoid factor by pleural tissue fragments from these patients was established using sensitive radioimmunoassays and by demonstration of the incorporation of leucine labelled with tritium into newly synthesised $\operatorname{IgM}$ by autoradiography. Results indicated that pleural tissue from patients with rheumatoid pleuritis synthesised IgM and IgM rheumatoid factor, whereas pleural tissue from control subjects and a patient with RA presenting with a non-rheumatoid pleural effusion (congestive heart failure) did not produce much IgM or IgM rheumatoid factor. In one patient with rheumatoid pleuritis, parallel studies indicated spontaneous IgM rheumatoid factor synthesis by pleural tissue and pleural fluid mononuclear cells in the absence of the synthesis of rheumatoid factor by peripheral blood mononuclear cells; in contrast, pleural fluid and peripheral blood mononuclear cells in the rheumatoid patient with a non-rheumatoid effusion functioned similarly in that comparable amounts of IgM and negligible amounts of $\operatorname{IgM}$ rheumatoid factor were elaborated.

These findings are remarkably similar to previous observations indicating local synthesis of rheumatoid factor and immunoglobulins in the synovium of patients with rheumatoid arthritis and coupled with evidence of complement activation and the presence of immune complexes in the pleural space support the proposal that rheumatoid pleuritis is an extravascular immune complex disease, as suggested by Zvaifler and others with respect to the synovitis of RA. ${ }^{3} 421$

\section{Pericardial disease}

The pericardium is a serosal membrane similar to synovium and pleura. Each of these tissues possess a microvasculature that constitutes a filter similar to that of the renal glomerulus which may trap antigen or immune complexes. ${ }^{1}$ The synovial membrane offers minimal resistance to the inflow of low molecular weight molecules and is subject to physical forces, particularly those associated with movement. ${ }^{22}$ These anatomical features have been implicated as playing a part in the vulnerability of the synovial membrane to the induction of inflammatory responses. ${ }^{23}$ Similar concepts are likely to apply to the pleural and pericardial membranes.

Pericarditis in RA is common at necropsy and is detected by echocardiography, but is rarely manifested clinically. ${ }^{13} 1924$ Earlier studies have suggested a part for local immunological events in the pathogenesis of the pericarditis of RA. Ball et al reported the presence of immunoglobulin complexes and decreased whole haemolytic complement activity in the peri-
Correspondence to: Dr James T Halla, 1927 Pine, Abilene, TX 79601, USA.

Accepted for publication 30 August 1991 
cardial fluid of a patient with RA. ${ }^{24}$ These immune complexes were present in greater concentration than in the patient's serum and were similar to those isolated by other workers from synovial fluids of patients with RA. Richards et al compared the immunological characteristics of serum, synovial fluid, and pericardial fluid from a patient with RA. ${ }^{25}$ Low complement levels and the presence of immune complexes detected by a biological assay based on histamine release were present in the synovial and pericardial fluids, whereas serum complement levels were normal and immune complexes were not seen in the blood. These studies are consistent with the local production of immunoreactants similar to that observed in the synovial membrane.

We studied pericardial tissue obtained from a patient with RA and clinical pericarditis. ${ }^{17}$ Immunofluorescence showed the presence of plasma cells in the pericardium of this patient. Moreover, dissociated mononuclear cells obtained from the pericardium synthesised IgA rheumatoid factor and IgM rheumatoid factor. Simultaneously obtained peripheral blood mononuclear cells elaborated IgA rheumatoid factor, whereas $\operatorname{Ig} M$ rheumatoid factor was not detected. These data provide direct evidence of the production of rheumatoid factor in a patient with rheumatoid pericarditis and suggest that this extra-articular manifestation of RA may also involve tissue based immune responses.

\section{Muscle disease}

Muscle disease is a recognised extra-articular manifestation of RA. ${ }^{1318192627}$ To determine the pathogenetic mechanisms underlying muscle inflammation in RA, muscle biopsy samples from 31 patients with various clinical activities as assessed by clinical and laboratory parameters were examined. ${ }^{18}$ Rheumatoid myositis, defined as muscle fibre necrosis and mononuclear cell infiltration, was observed in two groups of patients: those with a disproportionately increased erythrocyte sedimentation rate relative to objective evidence of synovitis, and those with active RA and increased levels of creatine kinase. Vasculitis in the muscle was a rare finding (1/15 patients with rheumatoid myositis). De novo synthesis of IgM and IgM rheumatoid factor from muscle tissue was noted only in patients with rheumatoid myositis. The pattern of immunoglobulin synthesis differed from that of peripheral blood mononuclear cells in that the ratio of $\operatorname{IgM}$ rheumatoid factor to total IgM synthesised was greater from the muscle tissue than from peripheral blood mononuclear cells cultured in vitro. Indirect immunofluoresence studies indicated the presence of immunoglobulin and complement deposits along the sarcolemmal membrane of patients with rheumatoid myositis, whereas patients with RA without rheumatoid myositis had little or no evidence of immune deposits as detected by immunofluorescence. These data indicate that lymphoid cells present in affected muscles are actively engaged in autoantibody (rheumatoid factor) synthesis as observed in synovium, pleura, and pericardium, in contrast with the relatively less (or undetectable) rheumatoid factor synthesis shown by simultaneously obtained peripheral blood cells.

The apparent absence of vasculitis in the muscle of these patients contrasts with the experience of some other workers. ${ }^{28} 29$ Bywaters has suggested that vasculitis is the main aetiological factor in all extra-articular manifestations of RA. ${ }^{28}$ Scott et al also emphasised the importance of vasculitis in many extra-articular features of RA. ${ }^{29}$ This assertion has been made in spite of the fact that most studies reporting histological findings in muscle of patients with RA do not show vasculitis but acute or chronic inflammation, or both, with mononuclear cell infiltrates. ${ }^{26} 27$ 30-34 This suggestion may have been influenced by the presumed relationship between vasculitis and rheumatoid nodules, although this has not been confirmed. ${ }^{35}$ The finding of local autonomy of the humoral immune response and the apparent lack of relationship between early nodule formation and vasculitis urges caution in accepting vaculitis as the aetiology of extraarticular manifestations in RA and is compatible with the view that local humoral immune responses, rather than systemic deposition of immune complexes, are pathogenetically important in at least extra-articular disease.

\section{Other organ disease}

Other workers have reported data suggesting local autonomy of the immune process in affected extra-articular organs in rheumatoid disease. Markenson et al studied a patient with pachymeningitis and RA. ${ }^{36}$ The meningitis was confined to the lumbar region and marked differences in levels of immunoglobulin, IgM rheumatoid factor, IgG rheumatoid factor, and immune complexes were noted in cerebrospinal fluid from the lumbar region compared with the cisternal region. These workers considered local production of rheumatoid factor as the most likely explanation for these findings. Mellors $e t$ $a l$, using immunofluorescent techniques, showed the presence of plasma cells containing rheumatoid factor in subcutaneous nodules and lymph nodes, and in the synovial membrane of patients with active RA. ${ }^{37}$

\section{Discussion}

The available data indicate the presence of functionally active B lymphocytes or plasma cells, or both, in several organs from rheumatoid patients with extra-articular disease and suggest that some extra-articular manifestations of RA share pathogenetic mechanisms with rheumatoid synovitis. The synovial membrane in RA is characteristically infiltrated by chronic inflammatory cells which may form cellular aggregates resembling lymphoid follicles. ${ }^{1} 3839$ In established rheumatoid synovitis, functionally active plasma cells in the synovial membrane synthesise and secrete immunoglobulins including rheumatoid factor. ${ }^{1-10} 3740$ Most of the plasma cells secrete IgG, IgA, and to a lesser degree, IgM. These locally synthesised immunoglobulins differ not only quantitatively 
from their serum counterparts, but also qualitatively as seen by: ( $a$ ) different isotype patterns of rheumatoid factor and total immunoglobulin elaborated by synovial plasma cells ${ }^{40-45}$; (b) different subclass patterns and electrophoretic mobility of the IgG produced by synovial lymphoid cells ${ }^{3} 424446 ;(c)$ different affinity and IgG subclass binding specificity of rheumatoid factor produced by synovial lymphoid cells ${ }^{45}$; and (d) preferential synthesis of rheumatoid factor by synovial plasma cells. ${ }^{7} 10$

The evidence reviewed has focused on available data which deals with the humoral arm of the immune response system. It seems reasonable to assume that the cellular arm of immunity plays a part in local extra-articular disease, as has been implicated for rheumatoid synovitis. ${ }^{47}{ }^{48}$ Further elucidation of the interaction of the humoral and cellular immune responses at extra-articular tissue sites remains to be determined.

The evidence summarised here suggests that local humoral immune responses contribute to the pathogenesis of some extra-articular manifestations of RA and synovial inflammation. These humoral local immune responses include the production of rheumatoid factor synthesis at local sites of inflammation, which is dissociable from rheumatoid factor synthesis by peripheral blood mononuclear cells; thus, RA may be considered as a polycentric disease in which immune events at local sites of tissue inflammation are autonomously regulated. Immunoreactants synthesised locally manifest qualitative differences from their counterparts in peripheral blood and probably contribute to immune complex formation in situ; these complexes also differ qualitatively from those present in the circulation. ${ }^{14}{ }^{15}$ It is highly probable that locally generated immune complexes initiate and perpetuate inflammation at affected tissue sites through activation of the complement cascade with attraction of polymorphonuclear leucocytes to the inflammatory site and attendant mediator and enzyme secretion.

The data discussed have focused on the production of rheumatoid factor as a prototype of immune responses at local sites of tissue injury. It should be stressed, however, that immune responses in the synovial membrane are not restricted to rheumatoid factor production. Indeed, there is convincing evidence for local synthesis of other antibody specificities. ${ }^{49-55}$ For instance, Tarkowski et al showed local collagen autoimmunity in some patients with RA as manifested by the production of antibody to type II collagen by synovial plasma cells in the absence of detectable antibodies to collagen II in serum samples. ${ }^{53}$ The presence of autoimmune responses at the site of tissue injury highlights the inadequacy of measuring serum antibody levels in patients with RA as a monitor of immunological events at sites of tissue inflammation. Similar conclusions have been drawn by Ford and coworkers ${ }^{49-52} 54$ with respect to the synovial lymphocyte response to certain viral and microbial antigens in reactive arthritis and RA and by Sigal et al ${ }^{55}$ for responses to Borrelia burgdorferi in Lyme disease.
Taken together, these data strongly indicate that humoral immune responses at sites of tissue injury in RA are distinct from those manifested in the periphery. Delineation of the pathogenesis of tissue destruction in RA, both articular and extra-articular, requires precise identification and characterisation of the specificity of these local responses.

This work was supported in part by National Institutes of Health grants AR03555 and AR20614 and the Veteran's Administration Research Program.

1 Harris E D. Pathogenesis of rheumatoid arthritis. In: Kelley W N, Harris E D, Ruddy S, Sledge C B, eds. Textbook of rheumatology Philadelphia: Saunders, 1989: 905-42.

2 Zvaifler N J. The immunopathology of joint inflammation in rheumatoid arthritis. Adv Immunol 1973; 16: 265-336.

3 Smiley J D, Hoffman W L, Moore S E, Paradies L H. The humoral immune response of the rheumatoid synovium. Semin Arthritis Rheum 1985; 14: 151-62.

4 Smiley J D, Sachs C, Ziff $M$. In vitro synthesis of immunoglobulin by rheumatoid synovial membrane. $\mathcal{C}$ Clin Invest 1968; 47: 624-32.

5 Sliwinski A J, Zvaifler $\mathbf{N}$ J. In vivo synthesis of IgG by rheumatoid synovium. $\mathcal{f}$ Clin Lab Med 1970; 76: 304-10.

6 Cecere F, Lessard J, McDuffy S J, Pope R M. Evidence for the local production and utilization of immune reactants in rheumatoid arthritis. Arthritis Rheum 1982; 25: 1307-15.

7 Wernick R M, Lipsky P E, Marban-Arcos E, Maliakkal J J, Edekbaum D, Ziff $M$. IgG and IgM rheumatoid factor synthesis in theumatoid synovial membrane cell cultures. Arthritis Rheum 1985; 28: 742-52.

8 Jones V, Taylor P C R, Jacoby R K, Wallington T B. Synovial synthesis of rheumatoid factors and immune complex constituents in early arthritis. Ann Rheum Dis 1984; 43: 235-9.

9 Egeland T, Lea T, Saari G, Mellbye O J, Natvig J B. Quantitation of cells secreting rheumatoid factor of IgG, IgA, and IgM class after eluation from rheumatoid synovial tissue. Arthritis Rheum 1982; 25: 1445-50.

10 Koopman W J, Miller R K, Crago S S, Mestecky J, Schrohenloher R E. IgA rheumatoid factor: evidence for independent expression at local sites of tissue inflammation. Ann NY Acad Sci 1983; 409: 258-71.

11 Ruddy S, Colten H R. Rheumatoid arthritis: biosynthesis of complement proteins by synovial tissue. $N$ Engl $\mathcal{F}$ Med 1974; 290: $1284-8$.

12 De Ceulaer C, Papazoglou S, Whaley K. Increased biosynthesis of complement components by cultured monocytes, synovial fluid macrophages and synovial membrane cells from patients with rheumatoid arthritis. Immunology 1980; 41: 37-43.

13 Decker J L, Plotz P. Extraarticular rheumatoid disease. In: McCarty D, ed. Arthritis and allied conditions. Vol. 9. Philadelphia: Lea and Febiger, 1979: 470-690.

14 Halla J T, Schrohenloher R E, Volanakis J E. Immune complexes and other laboratory featurees of pleural effusions: a comparison of rheumatoid arthritis, systemic lupus erythematosus and other diseases. Ann Intern Med 1980; 92: 748-52.

15 Halla J T, Schrohenloher R E, Volanakis J E. Observations on some properties of immune complexes in rheumatoid arthritis patient presenting with simultaneous synovitis and pleurisy. Arthritis Rheum 1980; 23: 1318-20.

16 Halla J T, Koopman W J, Schrohenloher R E, Darby W L, Heck L W. Local synthesis of IgM and IgM rheumatoid factor in rheumatoid pleuritis. F Rheumatol 1983; 10: $204-9$.

17 Spalding D M, Haber P L, Schrohenloher R E, Koopman W K. Production of immunoglobulin and rheumatoid factor by lymphoid cells in rheumatoid pericardium. Arthritis Rheum 1985; 28: 1071-4.

18 Halla J T, Koppman W J, Fallahi S, Oh S J, Ray R E, Schrohenloher R E. Rheumatoid myositis: clinical and histologic features and possible pathogenesis. Arthritis Rheum 1984; 27: 737-43.

19 Harris E D. The clinical features of rheumatoid arthritis. In: Kelley W N, Harris E D, Ruddy S, Sledge C, eds. Textbook of rheumatology. Philadelphia: Saunders, 1989: 943-87.

20 Hunder G G, McDuffie F C, Huston D A, Elveback L R, Hepper N G. Pleural fluid complement conversion and immune complexes in immunologic and nonimmunologic diseases. F Lab Clin Med 1977; 90: 971-80.

21 Zvaifler N J. Rheumatoid synovitis: an extravascular immune complex disease. Arthritis Rheum 1974; 17: 297-305.

22 Kushner I, Somerville J A. Permeability of human synovial membrane to plasma proteins: relationship to molecular membrane to plasma proteins: relationship to molecular

23 Zvaifler N J. Immunopathology of rheumatoid arthritis. In: Cohen A, ed. Mechanisms of immunopathology. New York: Wiley, 1979: 247-69.

24 Ball G B, Schrohenloher R E, Hester R. Gamma globulin complexes in rheumatoid pericardial fluid. Am $\mathcal{F}$ Med 1975 58: $123-8$.

25 Richards A J, Koehler B E, Broder I, Gordon D A. Rheumatoid pericarditis: comparison of immunologic characteristics of pericardial fluid, synovial fluid and characteristics of pericardial fluid,
serum. I Rheumatol 1976; 3: 275-82. 
26 Haslock D, Wright V, Harriman D G. Neuromuscular disorders in rheumatoid arthritis. $Q \mathcal{F}$ Med 1977; 39. 335-58.

27 Reza M, Verity M A. Neuromuscular manifestations of rheumatoid arthritis: a clinical and histomorphological analysis. Clin Rheum Dis 1977; 3: 565-88.

28 Bywaters E G. Vasculitis in rheumatoid arthritis in nonarticular forms of rheumatoid arthritis. In: Feltkamp T, ed. Proceedings of the IV ISRA symposium. The Hague: Netherlands League Against Rheumatism, 1976.

29 Scott D G, Bacon P A, Tribe C R. Systemic rheumatoid vasculitis: a clinical and laboratory study of 50 cases. Medicine (Baltimore) 1981; 60: 288-97.

30 Brennan S, Daly J. Large pleural effusions in rheumatoid arthritis. British Fournal of Diseases of the Chest 1979, $133-40$.

31 Walker $\mathrm{W}$, Wright $\mathrm{V}$. Pulmonary lesions and rheumatoid arthritis. Medicine (Baltimore) 1968; 47: 501-20.

32 Iveson J, Pomerance A. Cardiac involvement in rheumatic disease. Clin Rheum Dis 1967; 3: 467-500.

33 Thadani U, Iveson J, Wright V. Cardiac tamponade, constrictive pericarditis and pericardial resection in rheumatoid arthritis. Medicine (Baltimore) 1975; 54: 261-70.

34 Kaplan $\mathrm{H}$, Brooke $M$. Histochemical study of muscle in rheumatic disease. Arthritis Rheum 1971; 14: 168-75.

35 Rasker J, Kuiders F. Are rheumatoid nodules caused by vasculitis? A study of 13 early cases. Ann Rheum Dis 1983; 42: $384-8$

36 Markenson J A, McDougal J S, Tsairis P, Lockshin M D. Rheumatoid meningitis: a localized immune process. Ann Intern Med 1979; 90: 786.

37 Mellors R C, Heimer R, Corcos J, Korngold L. Cellular origin of rheumatic factor. 7 Exp Med 1959; 110: 875-86.

$38 \mathrm{Ziff} \mathbf{M}$. Relation of cellular infiltration of rheumatoid synovial membrane to its immune response. Arthritis Rheum 1974; 17: 313-9.

39 Maini R. Immunopathological mechanisms in rheumatoid arthritis at the dual interface of the synovial membrane: the joint cavity and the pannus. Triangle $1979 ; 18$ : 22-9.

40 Vaughan J H, Chihara T, Moore T L, et al. Rheumatoid factor-producing cells detected by direct hemolytic plaque factor-producing cells detected by direct

41 Munthe E, Natvig J B. Immunoglobulin classes, subclasses and complexes of IgG rheumatoid factor in rheumatoid plasma cells. Clin Exp Immunol 1972; 12: 55-70.

42 Natvig J B, Mellbye O J. Immunology in the pathogenesis of rheumatoid arthritis. Triangle 1979; 18: $39-44$.
43 Taylor-Upsaal M M, Abrahamsen T G, Natvig J B. Rheumatoid factor plaque-forming cells in rheumatoid synovial tissue. Clin Exp Immunol 1977; 28: 197-203.

44 Hoffman W L, Douglass R R, Smiley J D. Synthesis of electrophoretically restricted IgG by cultured rheumatoid synovium. Arthritis Rheum 1984; 27: 976-84.

45 Robbins D L, Benisek W F, Benjamin E, Wistar R Jr. Differential reactivity of rheumatoid synovial cells and serum rheumatoid factors to human immunoglobulin subclass 1 and 3 and their $\mathrm{CH} 3$ domains in rheumatoid arthritis. Arthritis Rheum 1987; 30: 489-97.

46 Hoffman W L, Goldberg M S, Smiley J D. Immunoglobulin $\mathrm{G}^{3}$ subclass production by rheumatoid synovial tissue cultures. F Clin Invest 1982; 69: 136-44.

47 Harris E. Rheumatoid arthritis: pathophysiology and implications for therapy. $N$ Engl $f$ Med 1990; 322 1277-89.

48 Krane S, Simon L. Rheumatoid arthritis: clinical features and pathogenetic mechanisms. Med Clin North Am 1986; 70: 263-84.

49 Ford D K, Da Roza D M, Schulzer M, Reid G D, Denegri J F. Persistent synovial lymphocyte responses to cytomegalovirus antigen in some patients with rheumatoid arthritis. Arthritis Rheum 1987; 30: 700-4.

50 Ford D K, Da Roza D M. Further observations on the responses of synovial lymphocytes to viral antigens in rheumatoid arthritis. $\mathcal{F}$ Rheumatol 1986; 13: 113-7.

51 Ford D K, Da Roza D M, Reid G D, Chantler J K, Tingle A J. Synovial mononuclear cell responses to rubella antigen in rheumatoid arthritis and unexplained knee arthritis. 7 Rheumatol 1982; 9: 420-3.

52 Ford D K, Stein H B, Schulzer M. Persistent synovial lymphocyte responses to mumps and adenovirus antigens. F Rheumatol 1982; 9: 420-3.

53 Tarkowski A, Klareskog L, Carlsten H, Herberts P, Koopman W J. Secretion of antibodies to collagens type I and II by synovial tissue cells in rheumatoid arthritis. Arthritis $R$ heum 1989; 32: 1087-92.

54 Ford D K, Da Roza D M, Schulzer M. The specificity of synovial mononuclear cell response to microbiological antigens in Reiter's syndrome. 7 Rheumatol 1982; 9: 561-9.

55 Sigal L H, Steere A C, Freeman D H, Dwyer J $\mathbf{M}$. Proliferative responses of mononuclear cells in Lyme disease: reactivity to Borrelia burgdorferi antigens is greater in joint fluid than in blood. Arthritis Rheum 1986; 29: 761-9. 